\title{
Chapter 17 \\ Feminization of Teaching: Female Teachers at Primary and Lower Secondary Schools in Baden-Württemberg, Germany: From Its Beginnings to the Present
}

\author{
Jürgen Schmude and Sascha Jackisch
}

\section{Object of Investigation}

In this article, we chronicle and explore the feminization process of the teaching profession in public primary and lower secondary schools (Grund-and Hauptschulen) for general education in the Grand Duchy of Baden from 1880 to 1918, the Republic of Baden from 1918 to 1952, and the Federal State of Baden-Württemberg from 1952 to 2015. This contribution can be understood as an update of Schmude's earlier work (1988). The factors that affected the feminization process on the primary and lower secondary school level and produced regional differences in the proportion of female teachers are diverse. They have also been identified in numerous national case studies for different periods (e.g., for Hungary by Meusburger \& Schmude, 1991; for the United States by Boyle, 2004; for Belgium by Depaepe, Lauwers, \& Simon, 2004; for France by Siegel, 2004; for the Netherlands by Timmerman, 2011), although their significance varies from country to country. Most of the analyzed factors are closely linked, making it extremely difficult to weigh their importance individually for the process of feminization. The analysis of the feminization of teaching must be seen in the context of women's increasing participation in the labor market, the greater number of women entering certain professions, and the process of feminization in the last 150 years. These topics have been discussed in politics as well as in the sciences for a long time. From today's perspective, the analysis of the feminisation process of the teaching profession is characterized by a shift of prioritization. Until the 1980s, researchers concentrated on understanding the long-term development of this process, taking into account the phenomena linked with it (e.g., spatial disparities). In contrast, the last 20 years of

\footnotetext{
J. Schmude $(\bowtie) \cdot$ S. Jackisch

Faculty of Earth Sciences, Department of Geography, Ludwig-Maximilans-University of Munich, München, Germany

e-mail: j.schmude@lmu.de; s.jackisch@lmu.de
} 
research have been dominated by the question of what the consequences of the feminisation process are. Some people interpret these changes as a sign of women's emancipation; others focus on gender's impact on, and consequences for, the execution of work.

As a consequence, the term feminization can be interpreted in at least two ways. The first refers to the timeline and the historical process by which women came to dominate the teaching profession in primary and lower secondary schools (Schmude, 1988). This numerical feminization is characterized by an increasing number of women in school education. The second deals with the loaded nature of the term feminization itself, which is often used to express that a feminized profession is slightly inferior, less serious, or less weighted (Maher, 2012). This can be interpreted as a cultural change or transformation of teaching. Researchers see feminine concerns, values, and practices as altering the culture of the educational system (Leathwood \& Read, 2009).

In Germany, as well as in many other countries, the teaching profession is often described as a feminized profession. However, the process of feminization in teaching developed differently at various levels of school education and reached different levels of feminization over time. In this article, we selected primary and lower secondary schools as empirical case studies because the process of feminization first began on this level and the proportion of women here is now the highest of all teaching professions. Additionally, the example of teachers on the primary and lower secondary school level is particularly suited for analyzing the feminization process in relation to time and space because these positions were, and are, nearly ubiquitous. In studying various factors that influenced the process of feminization, we directed a main focus of our inquiry on regional disparities as well as on the causal and correlative effects on women's participation in teaching. It is often difficult to distinguish between causes, effects and coincidences (Boyle, 2004). Moreover, the long-term consequences of the process of feminization are still of some interest.

\section{Methodology: Types of Numerical Feminization}

In this article, we define the degree of feminization by the share (percentage) of women among the teaching staff. However, we do not base our analysis of the process of feminization purely on the development of the share of female teachers, but also on the development of the absolute number of male and female teachers.

Stressing the development of the absolute number and the percentage of male and female teachers as well as the difference between their absolute numbers, three types of effective and one type of apparent feminization can be identified (see Fig. 17.1). We define effective feminization as an increasing share of female teachers among the teaching staff and a decreasing difference between the absolute numbers of male and female teachers. This can be caused by: 
a Effective Feminization

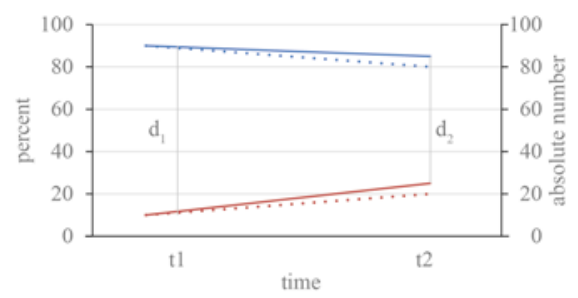

C Effective (passive) Feminization

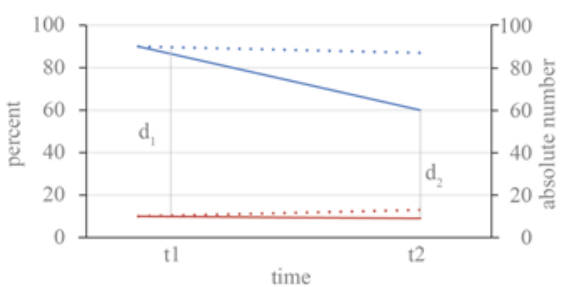

b Effective Feminization

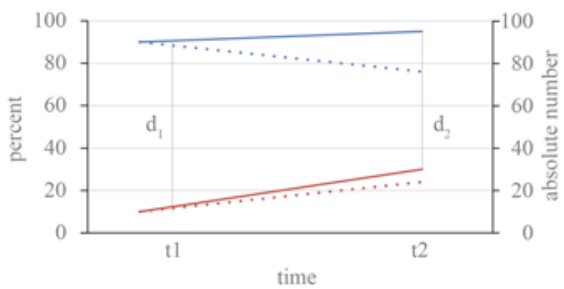

d Apparent Feminization

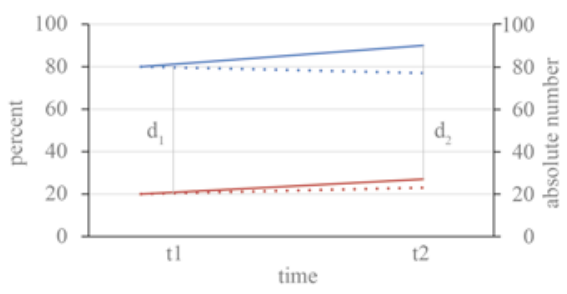

— male teachers (abs.) $\_$female teachers (abs.) $\cdots \cdots$ male teachers (rel.) $\cdots \cdots$ female teachers (rel.)

Fig. 17.1 Types of feminization. Adapted from Schmude, 1988, pp. 7-8. Copyright 1988 by Selbstverlag des Geographischen Instituts der Universität Heidelberg. Adapted with permission

- An increasing number of female teachers while the number of male teachers decreases or stagnates (Type A),

- A stronger increase of the number of female teachers compared to the number of male teachers (Type B), or

- A weaker decrease of the number of female teachers compared to the number of male teachers (Type C).

Type $\mathrm{C}$ can also be labelled as passive feminization, because the increasing share of female teachers among the teaching staff is not motivated by the substitution of male by female teachers, but rather by a sharper decline of the number of male teachers compared to the decrease of the number of female teachers.

In opposition to all three types of effective feminization, apparent feminization is recognized as:

- An increasing share of female teachers among the teaching staff, while the difference between the absolute number of male and female teachers is still increasing (Type D).

The process of feminization comes to an end or is interrupted as soon as the share of female teachers among the teaching staff decreases.

(a) Effective feminization

(b) Effective feminization

(c) Effective (passive) feminization

(d) Apparent feminization 


\section{Long-Term Development of the Feminization Process in Teaching at Primary and Lower Secondary Schools in Baden (1880-1952) and Baden-Württemberg (1952 Until 2015)}

Teaching at primary and lower secondary schools transitioned from a male occupation to a female occupation during the twentieth century. The gender proportion in the teaching profession changed slowly, and the degree of feminization as well as its causes have differed across time.

Stressing the full-time teaching profession in primary and lower secondary schools, four phases of effective feminization can be identified (see Fig. 17.2):

- The first two phases coincide with the time spans of World War I and II. These phases were characterized by a sharp drop in the number of male teachers whereas the number of female teachers increased (i.e., Type A).

- The third and most important phase of effective feminization took place from the 1950 s to 1975 . The number of female teachers grew much faster than the number of male teachers (i.e., Type B), which even decreased in some years (i.e., Type C). In this period, the size of the teaching staff rose steeply. More women than men were employed as teachers and female teachers formed the majority of the teaching staff for the first time in 1966. By 1975, the percentage of female teachers had reached its temporary peak at $57 \%$. The main reason behind the strong increase of teachers lies in the baby boom after World War II, which created the

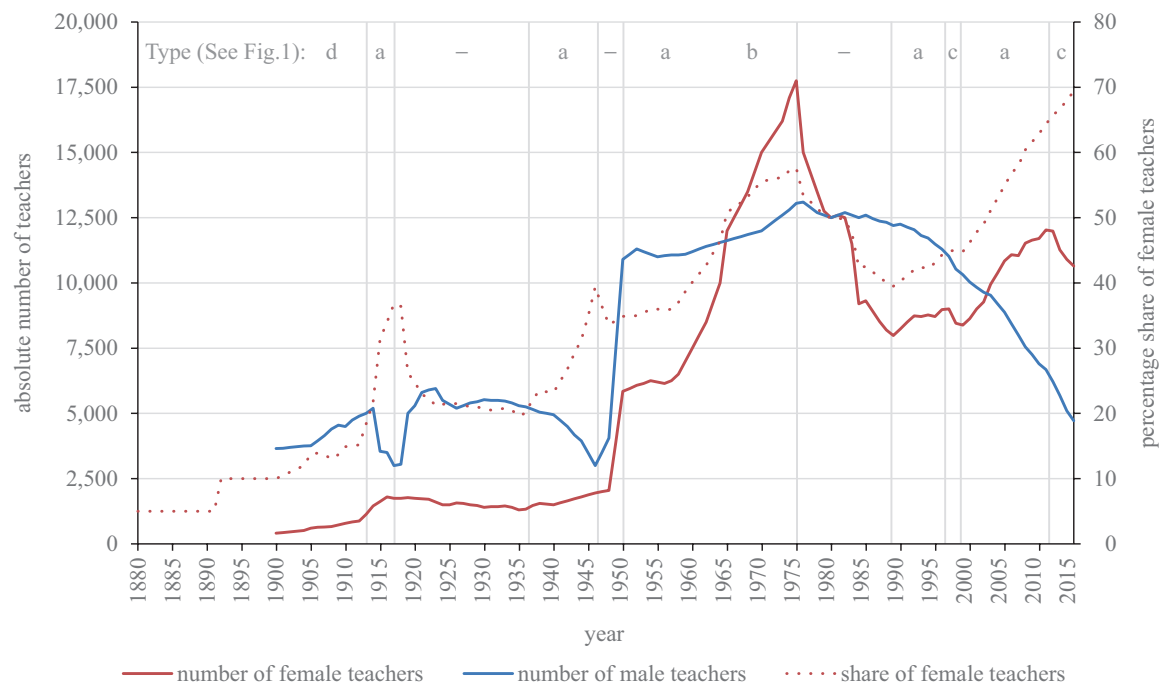

Fig. 17.2 The process of feminization of the teaching staff (full-time teaching) at primary and lower secondary schools from 1880 to 1951 in Baden and from 1952 to 2015 in BadenWürttemberg. Source: Design by author. Data from Schmude, 1988, p. 126; Statistisches Landesamt, 2017 
Table 17.1 Percentage of female teachers (full-time and part-time) by type of school in 1990, 2000, and 2015

\begin{tabular}{l|l|l|l}
\hline & Primary school & Secondary school & Grammar school \\
\hline $1990 / 1991$ & $63.2 \%$ & $45.6 \%$ & $34.8 \%$ \\
\hline $2000 / 2001$ & $70.9 \%$ & $53.1 \%$ & $42.3 \%$ \\
\hline $2015 / 2016$ & $81.5 \%$ & $63.9 \%$ & $57.6 \%$ \\
\hline
\end{tabular}

Source: Design by author. Data from Wolf (2009, pp. 4-5) and Statistisches Landesamt (2016, p. 32)

need for even more new teachers. The strong decrease of birth rates in the 1960s (the pill gap) caused a weaker demand for male and female teacher after 1975.

- In the fourth phase of effective feminization-which began in 1998 and continues to today - the percentage of female teachers reached its all-time peak at $69.3 \%$ in 2015 . This strong percentage increase was caused by an increase in the number of female teachers while the number of male teachers decreased (from 1998 to 1996, and from 1999 to 2011; i.e., Type A).

All other periods were either eras of passive feminization (1996-1999 and 20112015; i.e., Type C), apparent feminization (1880-1913; i.e., Type D), or interrupted processes of feminization (1917-1936, 1946-1950, and 1975-1988). The decrease in the share of female teachers on the teaching staff was caused by recessions in the 1970s and 1980s as well as by a decline in birth rate, which led to staff cuts in public schools and the elimination of many teaching jobs.

In contrast to primary and lower secondary schools, the process of an (effective) feminization at the grammar and high school level started much later and never reached the degree of feminization of the primary and lower secondary schools, even when part-time teaching is taken into account (see section below). In 2015, the share of female teachers in Baden-Württemberg reached $81.5 \%$ on the primary school level, although the share of female teachers was only $63.9 \%$ and $57.6 \%$ in lower and upper schools (see Table 17.1). Obviously, there is still a noticeable difference between women's opportunities in certain school types (Basten, 1997) and career levels. Beneath the hierarchy of education, the social status of teaching and the role model of teachers (see section below) has affected the feminization process as well. As a consequence, women still hold few jobs with administrative power. Historically, school directors and seminar leaders have mostly been men, and continue to be so today.

\section{Characteristics, Causes, and Effects of the Feminization Process}

At the end of the nineteenth century, in the Grand Duchy of Baden, as well as in many other countries, regional differences in the process of feminization were mainly caused by legislative impacts on the teaching license for women, by the network of school locations, by teachers' function outside the school, and by the framework of social conditions. 


\section{Urban-Rural Disparities: Legislative Impacts of Educational Authorities and the Network of School Locations}

Researchers of the social sciences and economics have long used community and/ or city size as an important variable to explain the differentiation and complexity of the economy and society. This indicator not only influences the qualification and job structure of the female labor force, but also the proportion of women employed in a specific occupation. This relationship is particularly clear among ubiquitous occupations like primary and lower secondary school teaching.

In most European countries, a central-peripheral gradient on the percentage of female teachers has been evident since the first detailed statistics from the nineteenth century (Meusburger \& Schmude, 1991b). This was also the case in the Grand Duchy of Baden, where the regional differences in the sex proportion of the teaching staff at public schools can be observed from the very beginning of women being allowed to teach at the end of the nineteenth century. The development of the urbanrural gradient of the feminization degree, which persisted for decades, is attributable to the phase when women were permitted to teach in public primary schools in the Grand Duchy of Baden in 1880. In other countries (e.g., Austria or France), women were admitted into the teaching profession much earlier (e.g., Klingler, 1970).

The social innovation of the female teacher took root over many decades, principally in the larger cities due to several causes, some of which were particular geographical, social, economic, and legal conditions. In the Grand Duchy of Baden, a minimum size of the teaching staff (three teachers) was a prior condition for the employment of a female teacher. Moreover, the percentage of female teachers in Baden was limited to $5 \%$ per school. In 1892, the quota was raised to $10 \%$, and in 1900 the limitation was abolished. As $75 \%$ of the primary and lower secondary schools were small (one or two teaching positions) and were concentrated in small, rural communities in the south and north-east of Baden, a spatial gradient in the degree of feminization arose and persisted for decades. Vice versa, the urban-rural disparities were forced by the concentration of large schools in the larger cities of Baden. In 1910, about $77 \%$ of all positions for female teachers in public primary schools were installed in communities with at least 10,000 inhabitants, in contrast to only $45 \%$ of all posts for male teachers. The degree of feminization increased with the size of the communities (see Table 17.2). These urban-rural disparities can be observed in many other countries as well, such as Austria or Hungary (Meusburger \& Schmude, 1991a, 1991b).

The rural exodus in the time of industrialization supported these regional differences in the process of feminization, as most new schools were set up in larger and growing cities. After World War II, there was still a close relationship between the size of the community and the degree of feminization of its teaching staff. This impact of the community size on the feminization process can also be illustrated by the size of the schools, which shows a strong correlation with the community size: the more posts at a school, the higher the percentage of female teachers (see Table 17.3). 
Table 17.2 Distribution of the posts for female teachers and the degree of feminization of the teaching staff at public primary schools in Baden in 1910 compared to the size of the communities

\begin{tabular}{l|l|l}
\hline $\begin{array}{l}\text { Community size (number of } \\
\text { inhabitants) }\end{array}$ & $\begin{array}{l}\text { Distribution of posts for female } \\
\text { teachers }(\%)\end{array}$ & $\begin{array}{l}\text { Degree of feminization } \\
(\%)\end{array}$ \\
\hline $0-500$ & 0 & 0 \\
\hline $501-1000$ & 0 & 0 \\
\hline $1001-2000$ & 6.1 & 6.5 \\
\hline $2001-5000$ & 8.1 & 5.3 \\
\hline $5001-10,000$ & 8.1 & 5.4 \\
\hline Over 10,000 & 77.1 & 14.3 \\
\hline Total & 100.0 & 8.5 \\
\hline
\end{tabular}

Source: Design by author. Data from Schmude (1988, p. 33)

Table 17.3 Share of teaching posts for female teachers depending on school size measured by the number of teaching posts

\begin{tabular}{l|l}
\hline $\begin{array}{l}\text { Number of } \\
\text { teaching posts }\end{array}$ & $\begin{array}{l}\text { Share of teaching } \\
\text { posts for female } \\
\text { teachers (\%) }\end{array}$ \\
\hline 1 & 16.57 \\
\hline 2 & 29.14 \\
\hline 3 & 33.33 \\
\hline 4 & 35.06 \\
\hline 5 & 35.74 \\
\hline $6-10$ & 39.05 \\
\hline More than 10 & 44.56
\end{tabular}

Source: Design by author. Data from Schmude (1988, p. 83)

This relationship became stronger over time as the proportion of female teachers grew faster in bigger cities than in rural areas until the mid-1970s. The model of regression analysis (see Fig. 17.3) contains a nearly linear relationship between the size of the communities and the degree of feminization of their teaching staff in 1911, 1951, and 1975 ( $\mathrm{r}>0.9$ ). The strong centre-to-periphery decline in the proportion of female teachers grew over time to higher percentage values and remained stable for nearly 100 years. In the mid-1970s, the difference of the degree between small and big communities started to decrease. Nevertheless, even in 1984 the highest degree of feminization in the teaching staff was still to be found in the biggest communities. These spatial disparities can be observed even today-on a lower level -in Baden-Württemberg (Kühn, 2010) and in other parts of Germany as well, for example, in Bavaria (Künzel, 2014).

To summarize, the beginning of teaching in public schools by women was not only concentrated on the larger cities of Baden, but the diffusion of the innovation was almost exclusively limited to the urban milieu as well. The hypothesis "the larger the community where the school is located, the higher the proportion of female teachers in primary schools," can be confirmed. An additional reason for these spatial disparities lies in the limited career opportunities of men in rural areas. 


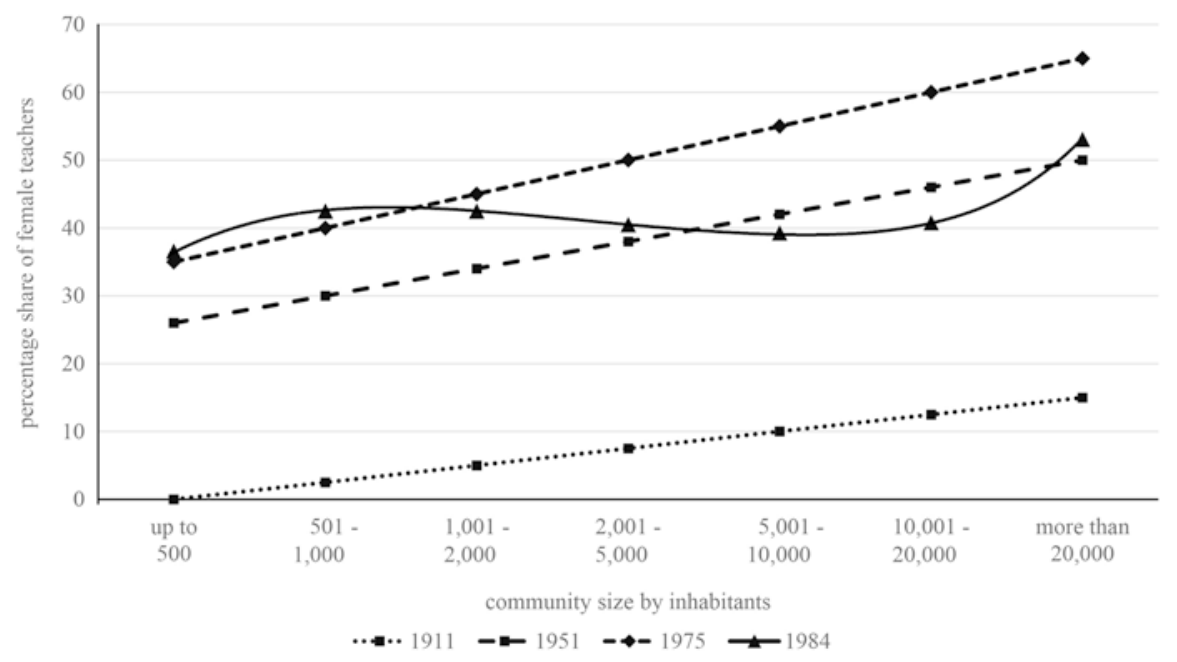

Fig. 17.3 Relationship between the degree of feminization among the teaching staff (full-time teachers) of primary and lower secondary schools and community size (inhabitants) in 1911 and 1951 (Baden), 1975 and 1984 (Baden-Württemberg). (Source: Design by author. Data from Schmude, 1988, p. 87)

As a consequence, teaching feminized more slowly in rural than in urban areas. Moreover, the feminization process was hindered by the fact that in the Grand Duchy of Baden, like in many countries, female teachers were usually forced to quit teaching once they married. In the 1930s, married women were banned from teaching by the so-called celibacy rule. As a result, there was almost no place in teaching for married women until the 1950s when the law was changed.

\section{Teachers' Function Outside the School and Their Social Background}

The divergent expectations of the urban and rural populations amplified urban-rural disparities in the degree of feminization (see previous section). Up to the second half of the twentieth century, the inhabitants of peripheral, rural areas expected teachers to take over various functions outside the school such as sexton, mayor, choir leader, or bandmaster. For almost all of these extrascholastic activities, the rural population preferred male teachers for various reasons, and women would not have been accepted in these positions (e.g., Meusburger, 1998). As a consequence of these expectations, female teachers refrained from applying for a position in rural regions. Contrastingly, in large cities these functions were taken over non-teachers. Moreover, the rural living conditions (e.g., lack of cultural facilities or the limited housing comforts), the isolation of rural areas (e.g., restricted public transport options), and the rigid social control exercised by villagers led to the assessment that rurally situated schools were not suitable for women. Taken together, these 
aspects influenced the application rate of female teachers and the allocation policy of the school authorities (Meusburger \& Schmude, 1991b). After World War II, these discrepancies in living conditions began to shrink, which began to improve the attractiveness of rural teaching posts.

As the teaching profession was one of the first in which women were allowed to practice, it attracted mostly well-educated women: "Women and society saw teaching as an appropriate career for them outside the home" (Boyle, 2004). Whereas female teachers at primary schools predominantly came from the metropolitan upper-class milieu (Twellmann, 1972), male teachers were overwhelmingly recruited from the rural lower- and middle-class milieu, meaning that they came from educationally deprived classes (Bieler, 2007). These sex-specific differences in recruitment correspond to the differences in the paternal occupation of male and female teachers (Nave-Herz, 1977). At the beginning of the twentieth century, most female teachers were daughters of officials, officers, or teachers of higher education. In contrast, male teachers tended to come from lower-middle-class backgrounds: The majority of the fathers of male teachers at primary schools worked as farmers or in blue-collar jobs. Most of the male teachers at primary schools had only completed primary school and becoming teachers served as an avenue for social mobility, whereas for many women teaching was a means of status maintenance (Rury, 1989). As a result of higher social classes in large cities, primary-school teaching was seen as an appropriate career for women but not for men (Meusburger \& Schmude, 1991b).

At the beginning of the twentieth century, sex-specific recruitment patterns were supported by the location of the teachers' training colleges: All three colleges for female teachers in the Grand Duchy were located in cities with at least 40,000 inhabitants, whereas four of the five colleges for male teachers were set up in small communities with less than 10,000 inhabitants.

In 1950, German educational authorities made secondary-school education a condition for teaching at primary schools. As a result, the traditional recruitment patterns, which were concentrated on male candidates from the rural milieu, shifted, and the number of female candidates surged. Consequently, the sociodemographic composition of the teaching staff at primary schools changed completely after World War II. One important factor was that men moved out of teaching at primary schools when better jobs were available for them, allowing more women to become teachers. This phenomenon is well known: In many cases, a profession's low prestige or loss of prestige is tied to its increasing feminization. In contrast, the greater the prestige and/or higher the financial attraction of a profession, the more difficult it is for women to advance in it.

\section{Labor-Market Aspects and the Demand for Teachers After World War II}

The degree of female participation in the labor market in general has an impact on the teaching profession's degree of feminization. In the former German Democratic Republic (GDR), where a higher share of women was working than in the Federal 
Republic of Germany (FRG), the share of women in the teaching staff was also noticeably higher. This difference was still seen more than 10 years after the reunification in 1989 (Kramer \& Schmude, 2005), even though the conditions have converged over time.

The process of feminization has been influenced not only by the aspects stated above but also by the demand for teachers. The feminization process has slowed down in times of reduced demand and sped up in times of greater demand. In times of an increasing need for teachers, such as the 1960s, recruitment campaigners targeted women, especially for primary schools. They launched several teachingrecruitment programs specific to women. In this way, women can be seen as a labor reserve or hidden reserve for the labor market. In other words, a great need for teachers always led to a greater than average proportion of female employment. In these periods, women were recruited even when they were not adequately qualified, which had a negative impact on the image of the teaching profession (Rothland \& Terhart, 2007). In contrast, times of reduced demand usually led to an underrepresentation in the recruitment of female teachers (e.g., in the 1980s) that resulted in a reversal or interruption of the feminization process. As a consequence, the rate of unemployed female teachers increased to a greater extent than that of male teachers (e.g., in 1985 about $77 \%$ of unemployed teachers in BadenWürttemberg were female). Moreover, the percentage of female teachers among unemployed teachers was higher than the share of women in the teaching staff: for example, $77.4 \%$ of all unemployed teachers versus $42.5 \%$ of all employed teachers in primary and intermediate schools in 1985 (Schmude, 1988, p. 104).

Another important influencing factor on the feminization process is the fact that the teaching profession is particularly suitable for part-time work and is, therefore, said to be highly compatible with family and children (Denzler \& Wolter, 2008; Wolter \& Denzler, 2003). Since the 1960s, the share of part-time teachers has risen strongly. As a result, in the mid-1980s more women were employed as part-time than as full-time teachers, whereas male teachers were usually full-time employees (see Fig. 17.4). These sex-specific differences in the proportion of full-time and part-time employment were still present in 2015. Consequently, the feminization rate for the whole teaching staff (full-time and part-time) reached higher percentages than the feminization rate of the full-time-employed teaching staff (e.g., in 2015: $84.5 \%$ vs. $69.3 \%)$.

Last but not least, the course of the feminization process shows a strong linkage to women and men's chosen fields of study (see Fig. 17.5). Because the teaching profession was one of the first jobs available for women, a high percentage of women decided to study teaching (e.g., 53\% of all female students in 1931). The dominance of teacher training for female students can be observed in the 1960s, and only since the 1990s has the share of teaching studies among female students decreased (1991: 14\%) and levelled off. The sex-specific differences in chosen fields of study have consequently narrowed, although a gap still exists (2009: 14\% of female students vs. $8 \%$ of male students chose teacher training as their field of study). 


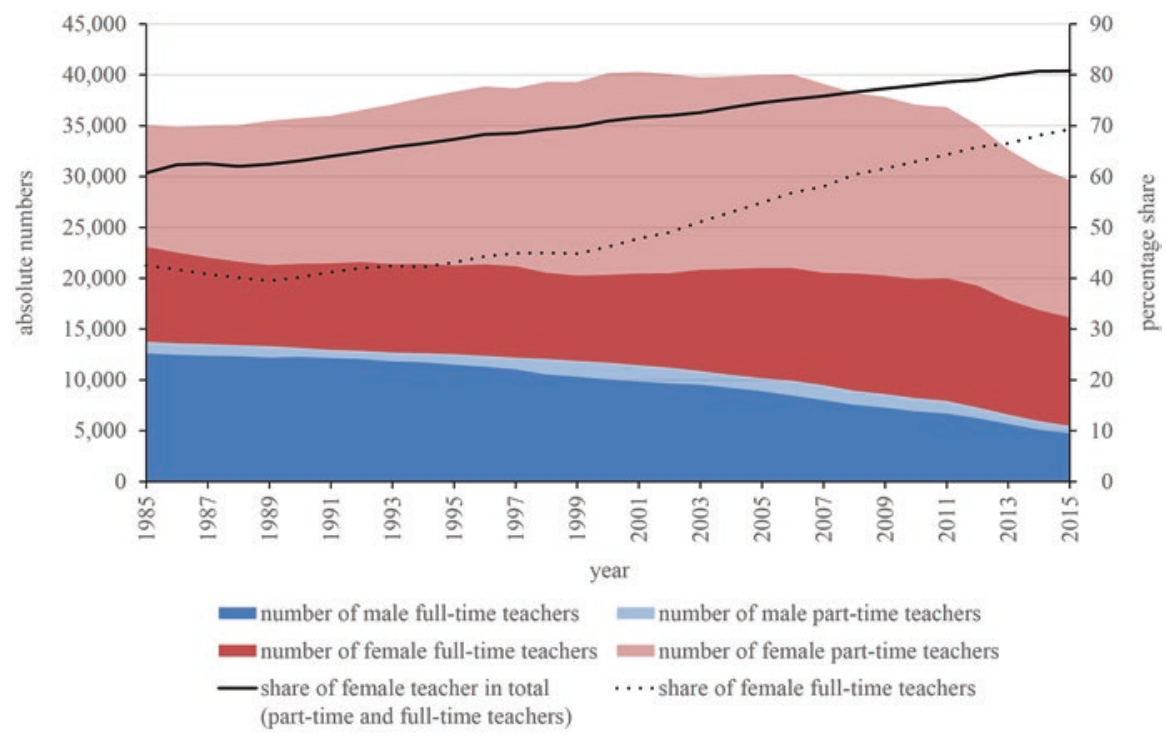

Fig. 17.4 The feminization process of the teaching staff (full-time and part-time teachers) of primary schools from 1985 to 2015 in Baden-Württemberg. Source: Design by author. Data from Schmude, 1988, p. 81, Statistisches Landesamt Baden-Württemberg, 2010, 2011, 2012, 2013, 2014, 2015, 2016, 2017; Wolf, 2009, pp. 4-5

\section{Consequences of the Numerical Feminization Process on the Teaching Profession}

During the past 150 years, particularly in countries with a long tradition of female teachers such the US and Great Britain, there has been a discussion about the supposed negative consequences of feminization for boys (Timmerman, 2011). For instance, Harvard President Charles Eliot was arguing against a too large proportion of female teachers as early as 1875 (Blair, 1979). At the beginning of the twentieth century, the feminization of teaching was seen not only as a cause for boys' problems in school, but for other educational problems and social crises as well (e.g., boys' failure to sufficiently develop a male identity).

At the end of the 1970s, the debates about the feminization process reached a new climax initiated by the publication of "Motherteacher" (Sugg Jr., 1978), whose author held feminization responsible for the failure of the US educational system. Critics claimed that the intellectual development of children suffered from antiintellectual, feminine pedagogy that was concentrated on children's social, creative, emotional, and moral skills. In literature, this feminine pedagogy became synonymous with soft pedagogy. "'Soft' pedagogy is contrasted to 'hard' pedagogy which is geared towards the desired levels of learning outcomes" (Dronkers, 2007, as cited in Timmerman, 2011, p. 470). Some authors asked whether feminization had gone too far. 

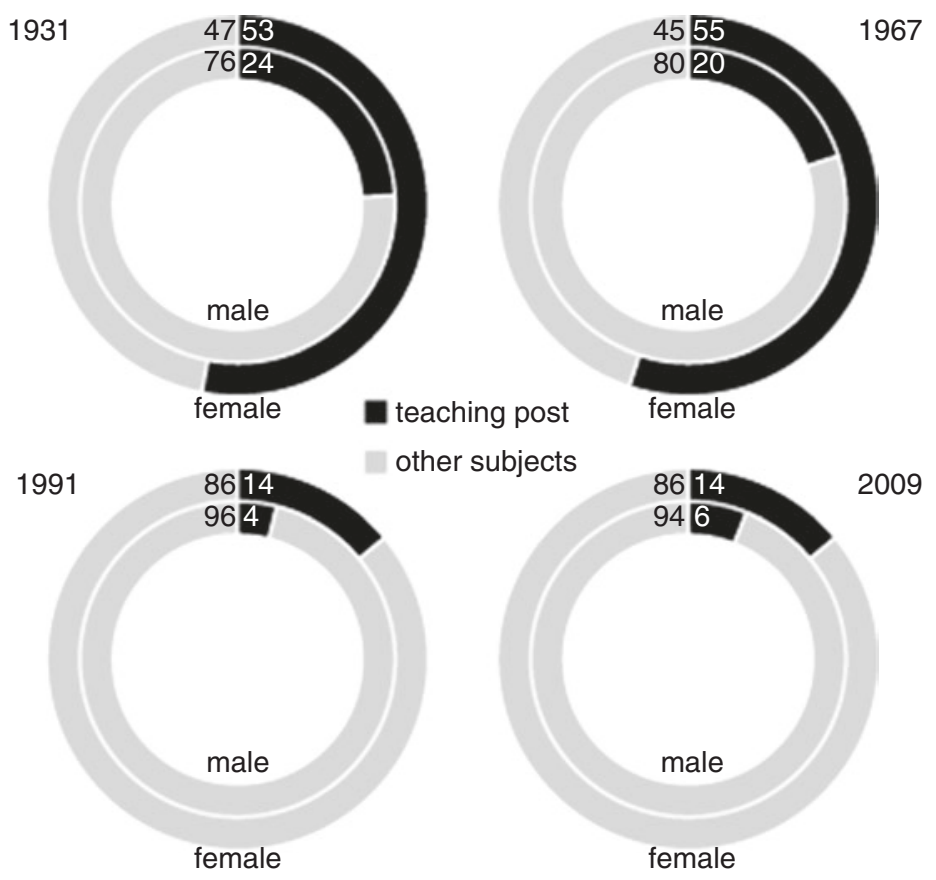

Fig. 17.5 Percentage of female and male teaching students as a share of all students in 1931, 1967, 1991, and 2009. Source: Design by author. Data from Lundgreen, 1999, p. 126; Statistisches Bundesamt, 2010, p. 198

Much research has been done to address the role of female teachers and the school performance gap between boys and girls (e.g., Holmlund \& Sund, 2008). There are distinct and contrasting theoretical positions in literature discussing the gender impact on education at primary-school level (see the literature review by Skelton, 2012 or Kelleher et al., 2011). For instance, Helbig (2010) stated that girls have become increasingly more successful in German schools than boys since the 1990s. Simultaneously, the share of female teachers in the school system has gradually grown. The underlying assumption is that the feminization of the teaching profession leads to a lack of male role models that may have negative consequences for the achievement and behavior of boys (Driessen, 2007). However, it remains unclear whether the feminization of teaching is actually the cause of girls achieving better results than boys. Attempts to prove this hypothesis have led to inconsistent results. With his ELEMENT study (2010), Helbig showed that boys do indeed receive lower degrees in mathematics and are consequently recommended for the high school slightly less frequently in schools with a high share of female teachers than in schools with lower share of female teachers. Additionally, girls have higher reading competencies in schools with a high share of female teachers. Therefore, some researchers (e.g., Mulvey, 2010) recommend separating boys and girls in single-sex classrooms, whereas others argue in favor of educating them in mixedsex classrooms because both boys and girls contribute to the classroom. Others, 
such as Skelton (2002), discuss whether a "re-masculinization" of primary education is necessary. In contrast, researchers such as Driessen (2007) could not find any effect of the share of female teachers on pupils' achievement, behavior, or attitudes. All in all, researchers conducting reviews in many countries have found little evidence of consistent advantages in either single-sex education or coeducation (Yates, 2011).

\section{Conclusion}

"Teaching at primary schools is one of the highly feminized 'semi-professions,' like nursery or library-keeping" (Boyle, 2004). The social status of the teaching profession at primary schools and the process of feminization have interacted as teaching's low status has allowed feminization, and feminization has contributed to teaching's low status (Thomas, 2012).

The analysis of the feminization process of primary schools in Baden respectively Baden-Württemberg has allowed us to identify a variety of factors responsible for central-peripheral disparities in women's teaching. Without a profound knowledge of regional geography and local history, these disparities cannot be explained sufficiently. These spatial disparities can be found on the regional scale (as in the case study of Baden-Württemberg) as well as on the national level.

Moreover, some of the factors have lost importance (e.g., size of teaching staff) whereas the influence of other factors has become stronger (in particular part-time employment). Additional factors influence the process of feminization and support the spatial differences of the share of female teachers in the teaching staff, such as teachers' salaries, economic frameworks, and local living conditions (e.g., Meusburger, 1998; Wolter, Denzler, \& Weber, 2003).

Whereas early researchers of the feminization process focused on numeric feminization, researchers have recently shifted more and more towards gender-related consequences of the process. In summary, it is clear that the process of feminization is still of academic interest and should be examined from a multidisciplinary perspective.

\section{References}

Basten, C. (1997). A feminised profession: Women in the teaching profession. Educational Studies, 23, 55-62. https://doi.org/10.1080/0305569970230104

Bieler, K. (2007). Im preußischen Schuldienst: Arbeitsverhältnisse und Berufsbiographien von Lehrerinnen und Lehrern in Berlin-Schöneberg 1871-1933 [Prussia's teaching profession: Employment relationships and professional biographies of female and male teachers in BerlinSchöneberg 1871-1933]. Cologne, Germany: Böhlau.

Blair, K. J. (1979). Motherteacher: The feminization of American education by Redding S. Sugg, Jr. The New England Quarterly, 52, 414-416. https://doi.org/10.2307/365636 
Boyle, E. (2004). The feminization of teaching in America. Retrieved from MIT's Program in Women's and Gender Studies website: https://stuff.mit.edu/afs/athena.mit.edu/org/w/wgs/ prize/eb04.html

Denzler, S., \& Wolter, S. C. (2008). Selbstselektion bei der Wahl eines Lehramtsstudiums: Zum Zusammenspiel individueller und institutioneller Faktoren [Self-selection into teacher training: On the interaction between individual and institutional factors]. Beiträge zur Hochschulforschung, 4, 112-141. Retrieved from http://www.bzh.bayern.de/uploads/media/42008-denzler-wolter.pdf

Depaepe, M., Lauwers, H., \& Simon, F. (2004). The feminization of the teaching profession in Belgium in the nineteenth and twentieth centuries. In R. Cortina \& S. San Román (Eds.), Women and teaching: Global perspectives on the feminization of a profession (pp. 155-183). New York: Palgrave Macmillan.

Driessen, G. (2007). The feminization of primary education: Effects of teachers' sex on pupil achievement, attitudes and behaviour. International Review of Education, 53, 183-203. https:// doi.org/10.1007/s11159-007-9039-y

Dronkers, J. (2007). Ruggengraat van ongelijkheid: Beperkingen en mogelijkheden om ongelijke onderwijskansen te veranderen [Backbone of inequality: Constraints and possibilities to change inequalities in educational opportunities]. Amsterdam: Mets \& Schilt.

Helbig, M. (2010). Sind Lehrerinnen für den geringeren Schulerfolg von Jungen verantwortlich? [Are female teachers responsible for the lower school success of boys?]. Kölner Zeitschrift für Soziologie und Sozialpsychologie, 62, 93-111. https://doi.org/10.1007/s11577-010-0095-0

Holmlund, H., \& Sund, K. (2008). Is the gender gap in school performance affected by the sex of the teacher? Labour Economics, 15, 37-53. https://doi.org/10.1016/j.labeco.2006.12.002

Kelleher, F., Afamasaga-Wright, T., De, A., Khaahloe, M. B., Samson, M., Sedere, U. M., et al. (2011). Women and the teaching profession: Exploring the feminisation debate. London: Commonwealth Secretariat.

Klingler, J. (1970). Wird der Lehrerberuf ein Frauenberuf? [Is the teaching profession becoming a female profession?]. Kölner Zeitschrift für Soziologie und Sozialpsychologie, 22, 39-61.

Kramer, C., Schmude, J. (2005). Frauen auf dem Vormarsch?! Die Feminisierung des Lehrberufs [Women on the move?! The feminization of teaching]. Leibniz-Institut für Länderkunde, H. Faßmann, B. Klagge, P. Meusburger, Arbeit und Lebensstandard (92-93). Nationalatlas Bundesrepublik Deutschland: Vol. 7. Heidelberg, Germany: Spektrum.

Kühn, A. (2010). Frauen in Bildungsberufen [Women in educational professions]. Statistisches Monatsheft Baden-Württemberg, 4, 25-28. Retrieved from https://www.statistik-bw.de/ Service/Veroeff/Monatshefte/PDF/Beitrag10_04_04.pdf

Künzel, J. (2014). Aspekte zur Feminisierung des Lehrberufs ausgewählter Gebiete im Bezirk Oberbayern [Aspects of feminization of the teaching profession in the district of Upper Bavaria]. Unpublished bachelor thesis. Munich, Germany: Department for Geography, Ludwig-Maximilians-University Munich.

Leathwood, C., \& Read, B. (2009). Carole Leathwood and Barbara Read: Gender and the changing face of higher education: A feminized future? Higher Education, 61, 613-616. https://doi. org/10.1007/s10734-010-9345-3

Lundgreen, P. (1999). Die Feminisierung des Lehrerberufs: Segregierung der Geschlechter oder weibliche Präferenz? Kritische Auseinandersetzung mit einer These von Dagmar Hänsel [Feminization of the teaching profession: Gender segregation or female preference? Critical reflection of Dagmar Hänsels' hypothesis]. Zeitschrift für Pädagogik, 1, 121-135. Retrieved from https://www.pedocs.de/volltexte/2012/5942/pdf/ZfPaed_1999_1_Lundgren_ Feminisierung_des_Lehrerberufs.pdf

Maher, F. A. (2012). Feminization of teaching. In J. A. Banks (Ed.), Encyclopedia of diversity in education (pp. 901-905). Thousand Oaks, CA: Sage. 
Meusburger, P. (1998). Bildungsgeographie: Wissen und Ausbildung in der räumlichen Dimension [Geography of education: The spatial dimension of knowledge and education]. Heidelberg, Germany: Spektrum.

Meusburger, P., \& Schmude, J. (1991a). Regionale Disparitäten in der Feminisierung des Lehrerberufs an Grundschulen (Volksschulen): Dargestellt an Beispielen aus Österreich, Baden-Württemberg und Ungarn [Regional disparities of the feminization of the teaching profession at primary schools: Described in the examples of Austria, Baden-Württemberg, and Hungary]. Geographische Zeitschrift, 79, 75-93.

Meusburger, P., \& Schmude, J. (1991b). The relationship between community size, female employment rates and the educational level of the female labour force (Monographs of the IGU Working Group "Gender and Geography" No. 12). Newcastle, UT.

Mulvey, J. D. (2010). The feminization of schools: If young boys are being left behind, what targeted teaching strategies can help them reach their potential? Education Digest, 75(8), 35-38. Retrieved from https://www.researchgate.net/publication/234652858_The_Feminization_of_ Schools_Young_Boys_Are_Being_Left_behind_What_Targeted_Teaching_Strategies_Can_ Help_Them_Reach_Their_Potential

Nave-Herz, R. (1977). Die Rolle des Lehrers: Eine Einführung in die Lehrersoziologie und in die Diskussion um den Rollenbegriff [The role of the teacher: An introduction to the sociology of teaching and to the discussion of the term "role"]. Neuwied, Germany: Luchterhand.

Rothland, M., \& Terhart, E. (2007). Beruf: Lehrer-Arbeitsplatz: Schule: Charakteristika der Arbeitstätigkeit und Bedingungen der Berufssituation [Profession: Teacher-workplace: School: Characteristics of the operations and conditions of the professional situation]. In M. Rothland (Ed.), Belastung und Beanspruchung im Lehrerberuf: Modelle, Befunde, Interventionen (pp. 11-31). Wiesbaden, Germany: VS Verlag für Sozialwissenschaften. https:// doi.org/10.1007/978-3-531-90500-6_2

Rury, J. (1989). Who became teachers? The social characteristics of teachers in American history. In D. Warren (Ed.), American teachers: Histories of a profession at work (pp. 9-48). New York, NY: Macmillan.

Schmude, J. (1988). Die Feminisierung des Lehrerberufs an öffentlichen allgemeinbildenden Schulen in Baden-Württemberg: Eine raumzeitliche Analyse [Feminization of the teaching profession at public schools in Baden-Württemberg: A temporal-spatial analysis]. Heidelberger Geographische Arbeiten: Vol. 87. Heidelberg, Germany: Selbstverlag des Geographischen Instituts der Universität Heidelberg.

Siegel, M. L. (2004). The moral of disarmament of France: Education, pacifism, and patriotism, 1914-1940. Cambridge, UK: Cambridge University Press.

Skelton, C. (2002). The "feminisation of schooling" or "re-masculinising" primary education? International Studies in Sociology of Education, 12, 77-96. https://doi. org/10.1080/09620210200200084

Skelton, C. (2012). Men teachers and the "feminised" primary school: A review of literature. Educational Review, 64, 1-19. https://doi.org/10.1080/00131911.2011.616634

Statistisches Bundesamt. (2010). Bildung und Kultur: Studierende an Hochschulen: Wintersemester 2009/2010 [Education and culture: Students at universities 2009/2010] (Subject-Matter Series 11, Series 4.1). Wiesbaden, Germany: Statistisches Bundesamt.

Statistisches Landesamt Baden-Württemberg. (2010). Statistische Berichte Baden-Württemberg: Allgemeinbildende Schulen in Baden-Württemberg im Schuljahr 2009/10 [Statistical reports Baden-Württemberg: Public schools in Baden-Württemberg in the school year 2009/10]. Retrieved from https://www.destatis.de/GPStatistik/servlets/MCRFileNodeServlet/BWHeft_ derivate_00000473/3231_09001.pdf 
Statistisches Landesamt Baden-Württemberg. (2011). Statistische Berichte Baden-Württemberg: Allgemeinbildende Schulen in Baden-Württemberg im Schuljahr 2010/11 [Statistical reports Baden-Württemberg: Public schools in Baden-Württemberg in the school year 2010/11]. Retrieved from https://www.destatis.de/GPStatistik/servlets/MCRFileNodeServlet/BWHeft_ derivate_00000213/3231_10001.pdf

Statistisches Landesamt Baden-Württemberg. (2012). Statistische Berichte Baden-Württemberg: Allgemeinbildende Schulen in Baden-Württemberg im Schuljahr 2011/12 [Statistical reports Baden-Württemberg: Public schools in Baden-Württemberg in the school year 2011/12]. Retrieved from https://www.destatis.de/GPStatistik/servlets/MCRFileNodeServlet/BWHeft_ derivate_00000474/3231_11001.pdf

Statistisches Landesamt Baden-Württemberg. (2013). Statistische Berichte Baden-Württemberg: Allgemeinbildende Schulen in Baden-Württemberg im Schuljahr 2012/13 [Statistical reports Baden-Württemberg: Public schools in Baden-Württemberg in the school year 2012/13]. Retrieved from https://www.destatis.de/GPStatistik/servlets/MCRFileNodeServlet/BWHeft_ derivate_00003207/3231_12001.pdf

Statistisches Landesamt Baden-Württemberg. (2014). Statistische Berichte Baden-Württemberg: Allgemeinbildende Schulen in Baden-Württemberg im Schuljahr 2013/14 [Statistical reports Baden-Württemberg: Public schools in Baden-Württemberg in the school year 2013/14]. Retrieved from https://www.destatis.de/GPStatistik/servlets/MCRFileNodeServlet/BWHeft_ derivate_00004075/3231_13001.pdf

Statistisches Landesamt Baden-Württemberg. (2015). Statistische Berichte Baden-Württemberg: Allgemeinbildende Schulen in Baden-Württemberg im Schuljahr 2014/15 [Statistical reports Baden-Württemberg: Public schools in Baden-Württemberg in the school year 2014/15]. Retrieved from https://www.destatis.de/GPStatistik/servlets/MCRFileNodeServlet/BWHeft_ derivate_00013342/3231_14001.pdf

Statistisches Landesamt Baden-Württemberg. (2016). Statistische Berichte Baden-Württemberg: Allgemeinbildende Schulen in Baden-Württemberg im Schuljahr 2015/16 [Statistical reports Baden-Württemberg: Public schools in Baden-Württemberg in the school year 2015/16]. Retrieved from https://www.destatis.de/GPStatistik/servlets/MCRFileNodeServlet/BWHeft_ derivate_00009282/323115001.pdf

Statistisches Landesamt Baden-Württemberg. (2017). Lehrkräftestatistik-voll- und teilzeitbeschäftigte Lehrkräfte von 1985-2009 an allgemeinbildenden Grund- und Werkreal-/ Hauptschulen in Baden-Württemberg nach Geschlecht und Beschäftigungsart: Sonderauswertung vom 26.9.2017 [Statistics of the teaching staff-full-time and part-time employed teachers 1985 to 2009 at public primary and lower secondary schools in BadenWürttemberg by sex and occupation type: Special analysis on 26.9.2017]. Stuttgart, Germany.

Sugg Jr., R. S. (1978). Motherteacher: The feminization of American education. Charlottesville, VA: University Press of Virginia.

Thomas, B. (2012). Der lange Weg der Frauen in den Lehrberuf: Von der Exotik zur Dominanz [The long way of women into the teaching profession: From exoticism to dominance]. In S. Hastedt \& S. Lange (Eds.), Männer und Grundschullehramt (pp. 31-43). Wiesbaden, Germany: VS Verlag für Sozialwissenschaften. https://doi.org/10.1007/978-3-531-18768-6_2

Timmerman, M. C. (2011). 'Soft' pedagogy? The invention of a 'feminine' pedagogy as a cause of educational crises. Pedagogy, Culture \& Society, 19, 457-472. https://doi.org/10.1080/146 81366.2011 .607837

Twellmann, M. (1972). Die deutsche Frauenbewegung: Ihre Anfänge und erste Entwicklung: 1843-1889 [The German women's movement: Founding history and initial development 1843-1889]. Marburger Abhandlungen zur politischen Wissenschaft: Vol. 17/2. Meisenheim am Glan, Germany: Anton Hain.

Wolf, R. (2009). Altersstruktur der Lehrerschaft an öffentlichen Schulen in Baden-Württemberg [Age structure of teachers at public schools in Baden-Württemberg]. Statistisches Monatsheft Baden-Württemberg, 8, 3-10. Retrieved from https://www.statistik-bw.de/Service/Veroeff/ Monatshefte/PDF/Beitrag09_08_01.pdf 
Wolter, S. C., \& Denzler, S. (2003). Ökonomische Erklärungen zur Feminisierung des Lehrberufes: Folgen anhaltender Diskriminierung von Frauen in der Privatwirtschaft. [Economic explanations of the feminization of the teaching profession: The consequences of lasting discrimination against women in the private sector]. Akzente, 4, 23-25. Retrieved from http://www. skbf-csre.ch/fileadmin/files/pdf/portraet/sw_PHZH.pdf

Wolter, S. C., Denzler, S., \& Weber, B. A. (2003). Betrachtungen zum Arbeitsmarkt der Lehrer in der Schweiz [Reflections on the labor market for teachers in Switzerland]. Vierteljahreshefte zur Wirtschaftsforschung, 72, 305-319. https://doi.org/10.3790/vjh.72.2.305

Yates, S. M. (2011). Single-sex school boys' perceptions of coeducational classroom learning environments. Learning Environments Research, 14, 1-10. https://doi.org/10.1007/ s10984-011-9079-x

Open Access This chapter is licensed under the terms of the Creative Commons Attribution 4.0 International License (http://creativecommons.org/licenses/by/4.0/), which permits use, sharing, adaptation, distribution and reproduction in any medium or format, as long as you give appropriate credit to the original author(s) and the source, provide a link to the Creative Commons license and indicate if changes were made.

The images or other third party material in this chapter are included in the chapter's Creative Commons license, unless indicated otherwise in a credit line to the material. If material is not included in the chapter's Creative Commons license and your intended use is not permitted by statutory regulation or exceeds the permitted use, you will need to obtain permission directly from the copyright holder.

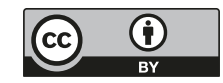

